Natural Hazards and Earth System Sciences (2001) 1: 233-242

(C) European Geophysical Society 2001

\title{
Tsunami risk assessment in the Marquesas Islands (French Polynesia) through numerical modeling of generic far-field events
}

\author{
H. Hébert, F. Schindelé, and P. Heinrich \\ Laboratoire de Détection et de Géophysique, CEA, BP12, 91680 Bruyères-le-Châtel, France
}

Received: 25 July 2001 - Revised: 21 December 2001 - Accepted: 8 February 2002

\begin{abstract}
Earthquakes occurring at the Pacific Rim can trigger tsunamis that propagate across the ocean and can produce significant damages far away from the source. In French Polynesia, the Marquesas Islands are the most exposed to the far-field tsunami hazards, since they are not protected by any outer coral reef and since submarine slopes are less steep than in other islands. Between 1994 and 1996, four tsunamis have reached the bays of the archipelago, among them, the tsunami initiated by the Chilean $M_{w} 8.1$ earthquake, produced up to $3 \mathrm{~m}$ high waves in Tahauku Bay. Numerical modeling of these recent events has already allowed us to validate our method of resolution of hydrodynamics laws through a finite-difference scheme that simulates the propagation of the tsunamis across the ocean and computes the inundation heights (run-up) in remote bays.
\end{abstract}

We present in this paper the simulations carried out to study potentially threatening areas located at the Pacific Rim, on the seismogenic Aleutian and Tonga subduction zones. We use a constant seismic moment source (that of the $M_{w}$ 8.1 Chile 1995 earthquake, $M_{0}=1.210^{21}$ N.m) located at several potential epicenters, with the fault strike adapted from the regional seismotectonics pattern. Our results show that the sources chosen in the Aleutian trench do not produce large inundations in the Marquesas bays, except for the easternmost source (longitude $194^{\circ} \mathrm{E}$ ). Sources located in the Tonga trench do not produce high amplifications either, except for the northernmost one (latitude $16^{\circ} \mathrm{S}$ ). We also discuss the behaviour of the tsunami waves within the archipelago, and evidence contrasting responses depending on the arrival azimuths. These results show that, for a given initial seismic energy, the tsunami amplification in remote bays is highly dependent on the source location and fault strike.

Correspondence to: H. Hébert

(hebert@dase.bruyeres.cea.fr)

\section{Introduction and objectives}

Strong earthquakes occurring around the Pacific Ocean can trigger tsunamis that are able to propagate across the whole ocean and reach remote islands. Such tsunamis have been generated, for instance, from the Aleutian Islands (1946) or the Chilean (1960) earthquakes and were observed thousands of kilometers away from their source area. The latter one (e.g. Cifuentes and Silver, 1989; Barrientos and Ward, 1990) reached the Marquesas Islands in French Polynesia and produced 7-8 $\mathrm{m}$ run-up heights in the bays (Heinrich et al., 1996). Even though a recent local cliff failure into the sea reminds us of the existence of a significant local tsunami hazard in the Marquesas Islands (Hébert et al., in press), the main tsunami hazard in the archipelago consists of the amplification of trans-Pacific tsunami waves.

The Marquesas Islands are the most prone to tsunami amplification in French Polynesia, since their large open bays are not protected by any outer coral reef and their surrounding submarine reliefs display milder slopes and shapes more concave than those of other Polynesian islands. Recently, the most striking tsunami observed in the archipelago was generated in 1995 by the $M_{w} 8.1$ Chilean earthquake (Ruegg et al., 1996): 2 to $3 \mathrm{~m}$ water heights above mean sea level were reported in Tahauku Bay in Hiva Oa. Again, in 1996, the tsunami initiated during the $1996 M_{w} 7.5$ Peruvian earthquake (Ihmlé et al., 1998) was observed in the Marquesas Islands, where more than $1 \mathrm{~m}$ water heights were reported at least in two bays. By contrast, tsunamis generated during the strong $1994 M_{w} 8.3$ Kurile (Tanioka et al., 1995; Ozawa, 1996; Piatanesi et al., 1999) and $1995 M_{w} 8.0$ ColimaJalisco earthquakes (Courboulex et al., 1997; Melbourne et al., 1997) were hardly observed in the bays of the Marquesas Islands.

The results concerning the numerical modeling of these recent events (Fig. 1) in the bays of the Marquesas Islands have already been reported elsewhere (Guibourg et al., 1997; Heinrich et al., 1998; Hébert et al., 2001). To summarize, they were in good agreement with the available observa- 


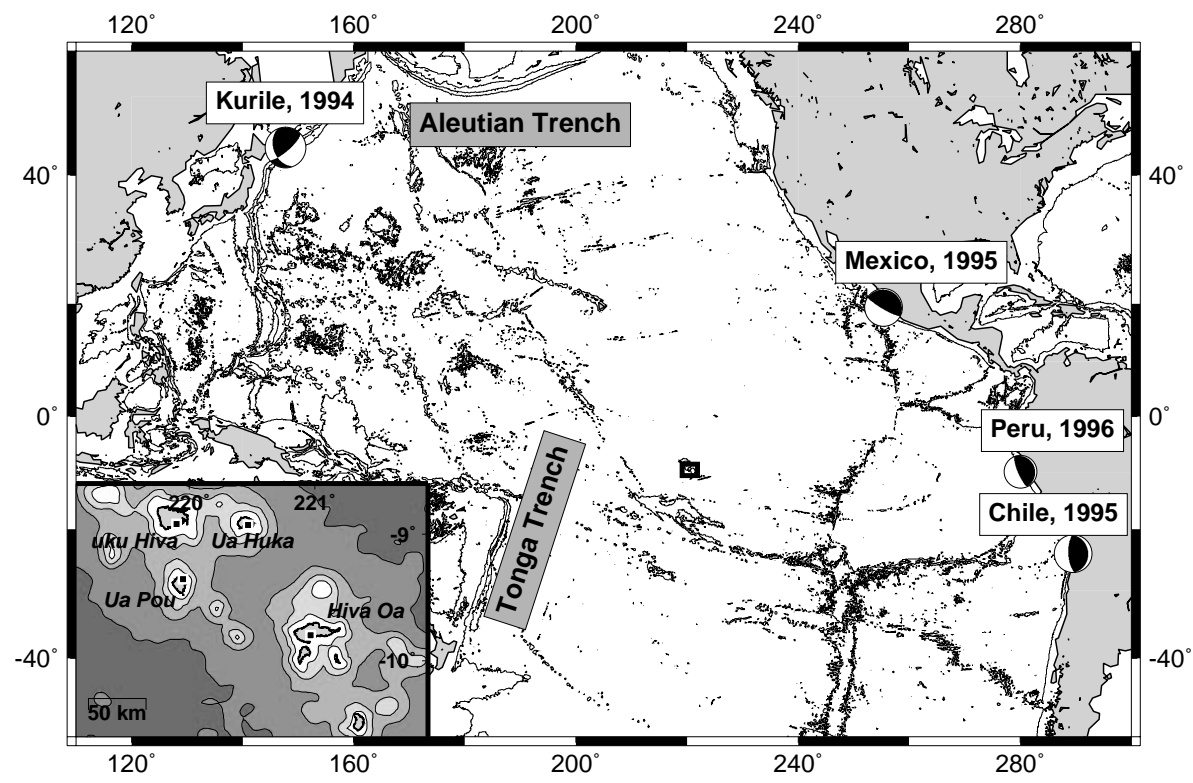

Fig. 1. Bathymetric map of the Pacific Ocean $(3000 \mathrm{~m}$ contours $)$ used for tsunami modeling (cell size 5') (Smith and Sandwell, 1997), and Harvard CMT solutions for the four recent earthquakes having generated transoceanic tsunamis. The seismogenic Aleutian and Tonga subduction zones studied in this paper are highlighted. The Marquesas archipelago (black rectangle in the middle of the Pacific Ocean) is particularly prone to tsunami amplification. The inset shows the bathymetry of the Marquesas archipelago and presents the four main islands and the four studied bays (black squares). tions, and they allowed us to validate the numerical model developed in our laboratory. Moreover, they helped to define South America as one of the most dangerous tsunami source area for the Marquesas archipelago, on the basis of the modeling of the four recent events, together with two additional generic events tested in the Aleutian and Tonga subduction zones. In the present paper, we aim at focusing on these two latter seismogenic subduction zones that are prone to generate large tsunamis, and to study whether these events could produce high inundation levels in the Marquesas bays.

\section{Method}

\subsection{Numerical model}

Tsunami propagation across the ocean obeys the classical hydrodynamics laws. Since tsunami wavelengths are much larger than the ocean depth, tsunamis are considered as shallow water waves. Hydrodynamics equations governing the motion of the tsunami are the continuity (1) and the momentum (2) equations:

$$
\begin{aligned}
& \frac{\partial(\eta+h)}{\partial t}+\nabla \cdot[\boldsymbol{v}(\eta+h)]=0 \\
& \frac{\partial(\boldsymbol{v})}{\partial t}+(\boldsymbol{v} . \nabla) \boldsymbol{v}=-\boldsymbol{g} \nabla \eta+\sum \boldsymbol{f},
\end{aligned}
$$

where $h$ is the sea depth, $\eta$ is the water elevation above mean sea level, $\boldsymbol{v}$ is the depth-averaged horizontal velocity vector, $\boldsymbol{g}$ is the gravity acceleration and $\boldsymbol{f}$ represents the bottom friction and Coriolis forces. These equations are solved in spherical coordinates by means of a finite-difference method, centered in time, using an upwind scheme in space (Guibourg et al., 1997). Though negligible in deep ocean, nonlinear terms in Eqs. (1) and (2) are taken into account at each grid point in our model, allowing us to deal with nonlinear effects close
Table 1. Parameters of the epicenters used for tsunami simulations in the Aleutian trench, with the shifted Chilean 1995 source. Dip $\left(19^{\circ}\right)$ and rake $\left(110^{\circ}\right)$ angles, fault depth $(36 \mathrm{~km})$ and dimensions $(180 \mathrm{~km} \times 60 \mathrm{~km})$, rigidity $\left(3.510^{10} \mathrm{~N} . \mathrm{m}^{-2}\right)$ and seismic moment $\left(1.210^{21}\right.$ N.m) are those used for the Chilean 1995 case (Hébert et al., 2001)

\begin{tabular}{cccccc}
\hline Longitude & $176^{\circ} \mathrm{E}$ & $180^{\circ} \mathrm{E}$ & $185^{\circ} \mathrm{E}$ & $190^{\circ} \mathrm{E}$ & $194^{\circ} \mathrm{E}$ \\
Latitude & $52.0^{\circ} \mathrm{N}$ & $51.3^{\circ} \mathrm{N}$ & $51.3^{\circ} \mathrm{N}$ & $52.2^{\circ} \mathrm{N}$ & $53.3^{\circ} \mathrm{N}$ \\
Strike & $285^{\circ}$ & $270^{\circ}$ & $260^{\circ}$ & $250^{\circ}$ & $250^{\circ}$ \\
\hline
\end{tabular}

to the shores. The wave velocity $c$ is given by $c=(g h)^{1 / 2}$ for small amplitudes, and thus the deeper the water, the faster the tsunami.

Initial conditions are provided by the deformation of the sea-floor during the earthquake. We assume that the initial sea water elevation is equal to the coseismic vertical displacement, since the coseismic deformation is considered to be instantaneous with respect to the tsunami propagation, and because the length scales of the sea-bottom deformation are large compared to the water depth. The initial sea-floor deformation is computed through the Okada (1985) formulas from the seismic source parameters. These fault parameters are provided by the moment tensor analysis of seismic waves, which allows one to determine the seismic moment $M_{0}=\mu U L W$, where $\mu$ is the rigidity, $U$ is the average slip amount and $L(W)$ is the length (width) of the fault plane.

The tsunami propagation is simulated by using several nested bathymetric grids characterized by a coarse resolution over deep water regions (Pacific Ocean, archipelago) and a fine resolution close to the shores (up to a grid cell size of $15 \mathrm{~m}$ in the bays). Wave heights and velocities along the boundaries of a fine grid are spatially interpolated at each 


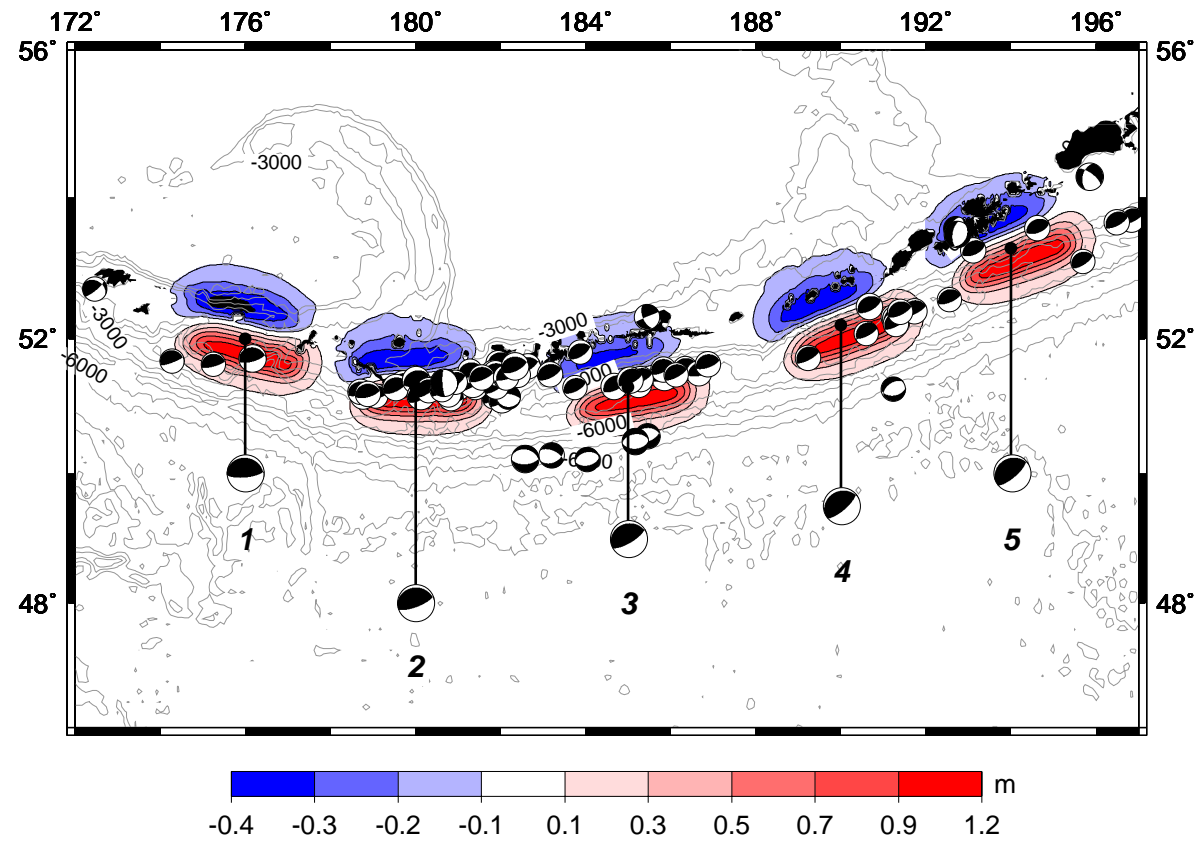

Fig. 2. Initial coseismic sea-floor deformations computed with the Okada (1985) formula for the five cases studied in the Aleutian trench. The five focal mechanisms are plotted with the parameters used for the computations (see Table 1). Other focal mechanisms from the Harvard CMT database (e.g. Dziewonski et al., 1987) display the seismicity since 1980 for $M_{w}$ magnitudes larger than 5.5. Bathymetric contours (each $1000 \mathrm{~m}$ ) are from the Smith and Sandwell (1997) data. time step from the values computed in the coarse grid containing the fine grid. The numerical method also allows us to predict the run-up values (height of inland tsunami inundation), provided the topography is known in the first emerged meters. Thus, both bathymetric and topographic data are needed for tsunami modeling. Global bathymetric data sets for the Pacific Ocean (Smith and Sandwell, 1997) have been used to build the bathymetric grid describing the Pacific Ocean (Fig. 1) and the Marquesas archipelago. Data digitized from French hydrographic maps and from topographic maps, where available, have been used for the finest grids. For each island a series of 3 nested bathymetric grids was built, describing first the whole island, second the area around the studied bay, and finally, the configuration of the bay, which includes both topographic and bathymetric features. All in all, 14 grids have been established for this study, the details of their construction have been given in our recently published paper (Hébert et al., 2001).

\subsection{Sources used for the study}

The first numerical modelings carried out for the four recent events dealt first with different initial moment magnitudes, and in a second step, we chose to simulate a generic tsunami event characterized by a constant initial energy, in order to study the behaviour of the waves only (Hébert et al., 2001). This is the method we use in the present study, with the same generic source defined by the $1995 M_{w} 8.1$ Chilean seismological parameters (arranged from Ruegg et al., 1996), and the fault strikes and epicenters adapted from the seismotectonics of each generation area. With this generic source, we investigate the Aleutian (five epicenters) and the Tonga (five epicenters) subduction zones.

\section{Simulation of tsunamis initiated in the Aleutian trench}

The Aleutian trench is one of the farthest threatening source areas as regarding the Marquesas archipelago, but strong earthquakes occur in the area and produce important transPacific tsunamis, such as the one in 1946. The study of this latter case is beyond the aim of this paper, and has already been discussed elsewhere on the basis of tsunami data (Johnson and Satake, 1997). Simulations have been performed in the present study to test various threatening source areas, by letting the strike angle of the fault vary for five epicenter locations between the western $\left(176^{\circ} \mathrm{E}\right)$ and the eastern $\left(194^{\circ} \mathrm{E}\right)$ Aleutian trench (Table 1). Maximum initial seafloor deformations computed with the Okada (1985) formula reach about $1.2 \mathrm{~m}$ for all cases (Fig. 2), with a mean displacement on the fault of about $3 \mathrm{~m}$.

\subsection{Behaviour in the Pacific Ocean}

Figure 3 displays the maximum water heights in the Pacific Ocean for the five cases in the Aleutian area. The map shows that the energy of the tsunami, at first order, is maximum in the direction perpendicular to the fault strike, as expected (Titov et al., 1999; Hébert et al., 2001). The tsunami waves are trapped on fracture zones and seamount chains of the northern Pacific Ocean. More specifically, tsunamis generated in the western Aleutian trench encounter the long Hawaiian ridge which partly stops the energy directed toward the western Pacific Ocean, but does not prevent the Marquesas Islands from being affected. From this map we observe that the maximum water heights reaching the archipelago range from less than 1 to about $3 \mathrm{~cm}$, the maximum being that generated from a source located in the eastern part of the 

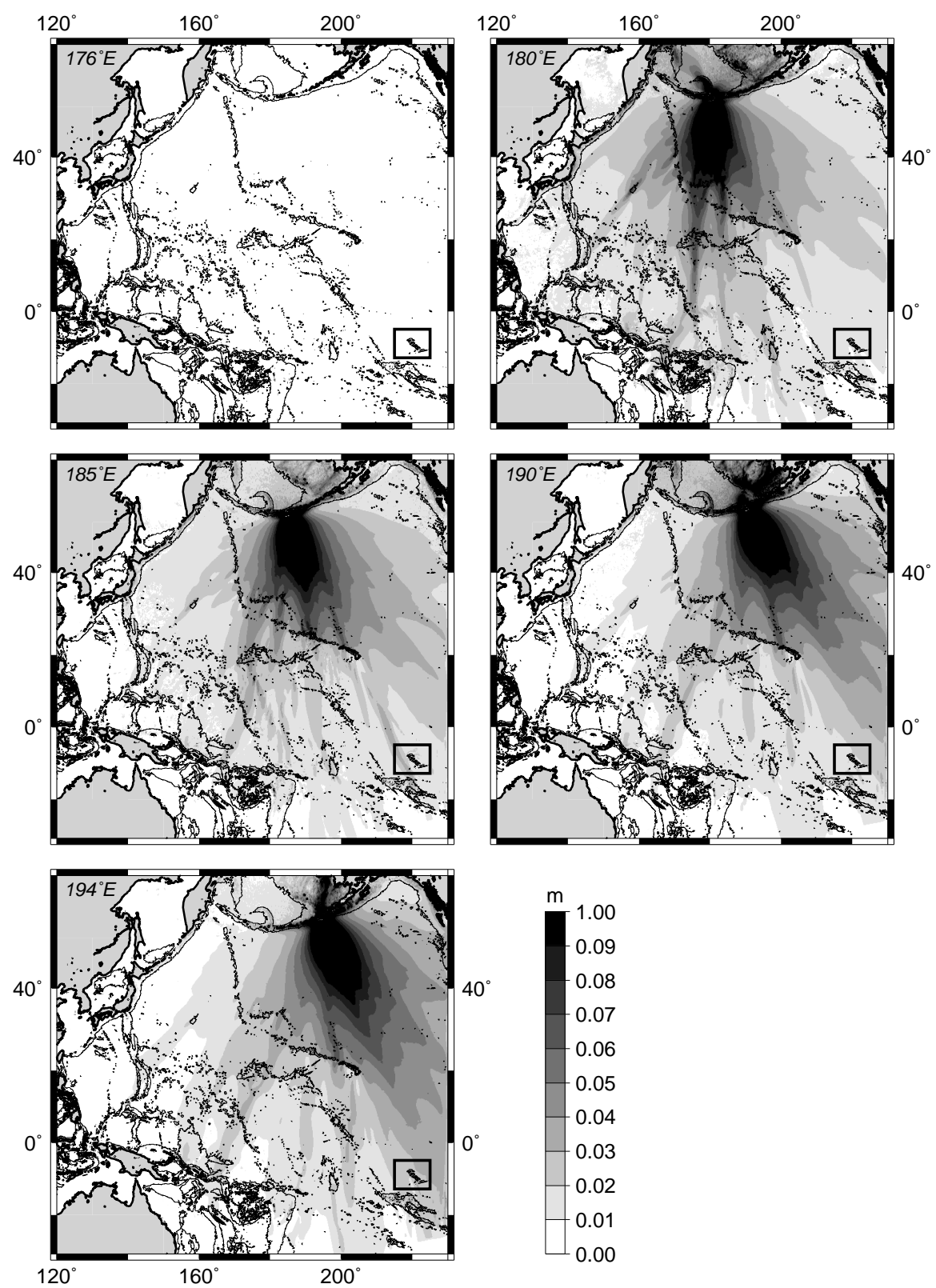

Fig. 3. Maximum water heights computed in the Pacific Ocean for the five tsunamis generated at the Aleutian trench $\left(176^{\circ} \mathrm{E}, 180^{\circ} \mathrm{E}, 185^{\circ} \mathrm{E}\right.$, $190^{\circ} \mathrm{E}$, and $\left.194^{\circ} \mathrm{E}\right)$. Note the role of the Hawaiian Ridge in trapping the energy of tsunamis generated in the western subduction zone. Average maximum water heights reaching the Marquesas archipelago range from 1 to $3 \mathrm{~cm}$.

trench $\left(194^{\circ} \mathrm{E}\right)$. We also note that the geometrical spreading of the energy for these simulations is quite uniform in the deep northern Pacific Ocean. This agrees with recent analytical work that showed that the deeper the sea-floor features (as is the case in the north Pacific), the smaller the induced scattering, particularly toward the Hawaiian ridge (Mofjeld et al., 2000). Finally, this map readily shows that the location of the source within the subduction zone determines the tsunami energy reaching the remote archipelago.

\subsection{Behaviour in the bays}

In order to study the amplification in the Marquesas bays, the propagation of the tsunami has been studied within the archipelago, following a method described in Hébert et al. (2001). The average of the maximum water height values has been computed at four gages at the archipelago boundaries, at a 4000 to $4500 \mathrm{~m}$ water depth (A), at four gages off each studied island, where the water depth is about $1900 \mathrm{~m}$ (B), at four gages off each studied bay, where the water depth is 70 to $100 \mathrm{~m}(\mathrm{C})$, at four gages at each bay entrance, where the water depth is 25 to $40 \mathrm{~m}$ (D) and finally, at four gages at each bay extremity, where the water depth is about $3-4 \mathrm{~m}$ (E), and this has been done for each studied tsunami. It is worth noting that the computed values are not normalized on the initial value (A), thus the obtained plot does not display the amplification factor sometimes used in tsunami studies, that allows one to deal with non dimensional values. In addition, the $x$-axis is not to scale here, thus the plots showed here are not really proper mathematical functions. However, 


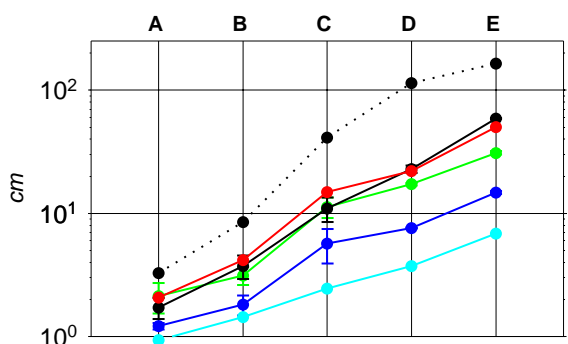
Tahauku Bay

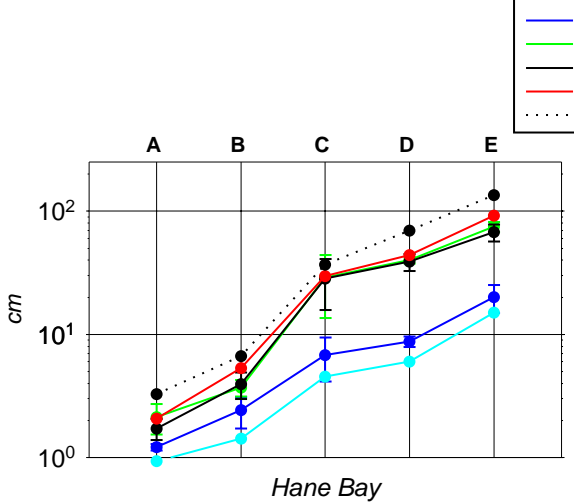

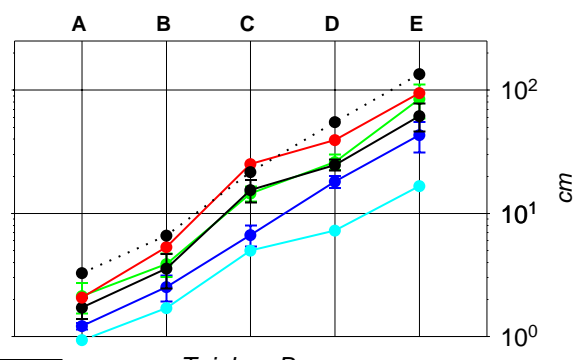

Taiohae Bay

\section{$176^{\circ} \mathrm{E}$}

$185^{\circ} \mathrm{E}$ $194^{\circ} \mathrm{E}$ Chile 95

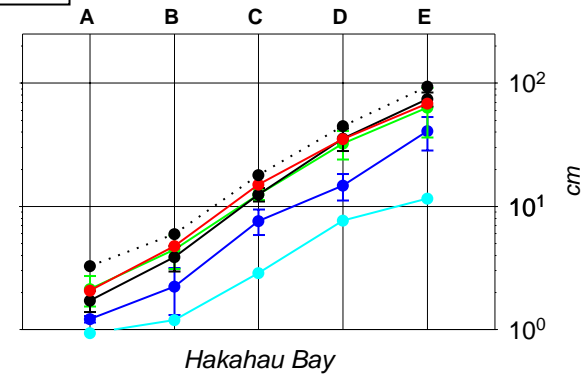

Fig. 4. Amplification functions plotted for the five simulated Aleutian and the Chilean 1995 tsunamis, for the four studied bays (Tahauku Bay in Hiva Oa Island, Taiohae Bay in Nuku Hiva Island, Hane Bay in Ua Huka Island, and Hakahau Bay in Ua Pou Island). Each letter (from A to E) stands for 4 gages located beneath a water depth of about $4500 \mathrm{~m}$ (A), $1900 \mathrm{~m}$ (B), 70-100 m (C), 25-40 m (D), and 3-4 m (E). Each plain circle ordinate represents the average of the 4 maximum water heights computed at the gages, after about $2 \mathrm{~h}$ propagation time in the archipelago, and the error bar represents the standard deviation of these 4 values. we report here average values that describe well the shoaling effect, allowing us to discuss the absolute amplification in the bays.

The obtained values are plotted in Fig. 4 (error bars display the standard deviation with respect to the mean value), for the five theoretical tsunamis characterized by the same initial seismic moment. First, we observe that the maximum water heights computed at averaged gages $\mathrm{A}$ range from less than 1 to at least $2 \mathrm{~cm}$, in rather good agreement with the values roughly estimated in Fig. 3 around the archipelago. Then, the western $\left(176^{\circ} \mathrm{E}\right)$ case displays the lowest maximum wave heights for the four different bays, from 7 to $20 \mathrm{~cm}$ (gages E). Highest amplifications (60 to $100 \mathrm{~cm}$ ) occur for sources located in the eastern subduction zone, either at $190^{\circ} \mathrm{E}$ or $194^{\circ} \mathrm{E}$, but values obtained in the extremities of the bays for the $185^{\circ} \mathrm{E}$ source are very close as well. The $180^{\circ} \mathrm{E}$ source appears as an intermediate one, leading to maximum water heights between 20 and $40 \mathrm{~cm}$ at averaged gages E. Similar values computed for the tsunami generated during the Chilean 1995 earthquake (same initial seismic moment as for the generic cases) have been reported on the same plot in Fig. 4 (dotted line). We note that the initial maximum water heights around the archipelago are significantly larger than for the Aleutian sources and reach at least $3 \mathrm{~cm}$, despite a longer propagation time $(10 \mathrm{~h}$ instead of about $9 \mathrm{~h}$ for the Aleutian cases, probably due to a higher wave velocity related to larger water depths in the northern Pacific Ocean for the latter). The striking difference is the behaviour in Tahauku Bay, where the Chilean tsunami is much more amplified than the Aleutian tsunamis, leading to more than $100 \mathrm{~cm}$ at gages $\mathrm{E}$ for this bay. For the other bays, the behaviour of the Chilean tsunami is similar to the behaviour of the eastern Aleutian tsunamis (from $185^{\circ} \mathrm{E}$ to $194^{\circ} \mathrm{E}$ ), and the final values are about $100 \mathrm{~cm}$, even though the initial average value at gages $\mathrm{A}$ was higher for the Chilean tsunami. This comparison underlines a particular behaviour for Hiva Oa Island: indeed, Tahauku Bay is open eastwards (see Fig. 1) and may be prone to amplification for tsunamis arriving from South America. On the other hand, the same bay may be protected from tsunamis coming from the Aleutian subduction zone because of the other islands located northwards. The only bay opened northwards that could be prone to amplification for Aleutian tsunamis is Hakahau Bay (Ua Pou), but it is probably protected by Nuku Hiva and Ua Huka (Fig. 1).

Figure 5 focuses on the maximum water heights computed in the Hane Bay for the five studied cases, $2 \mathrm{~h}$ after the arrival of the first wave of the tsunami. It must be noted that the maximum values obtained here are larger than the values displayed in Fig. 4, since the gages $\mathrm{E}$ are not located at the extremities of the bay. For the $176^{\circ} \mathrm{E}$ and $180^{\circ} \mathrm{E}$ cases, the maximum water heights do not exceed $30-40 \mathrm{~cm}$ at the northern extremity of the bay. For the $185^{\circ} \mathrm{E}$ and $190^{\circ} \mathrm{E}$ cases the maximum water heights reach about $120 \mathrm{~cm}$ at the northern extremity of the bay, while the $194^{\circ} \mathrm{S}$ case, provokes a slightly higher maximum wave height in the bay, with about $140-150 \mathrm{~cm}$ at the extremity of the bay. These maximum computed values are smaller than the ones previously obtained in the same bay for the tsunami generated during the Chilean (1995) earthquake (almost $180 \mathrm{~cm}$ ), as it was already noted in Fig. 4 for averaged values at different gages. Finally, the obtained run-up values are much smaller than the inundations observed during the 1946 tsunami, for an epicenter latitude of about $196^{\circ} \mathrm{E}$. However, the 1946 epicenter was 


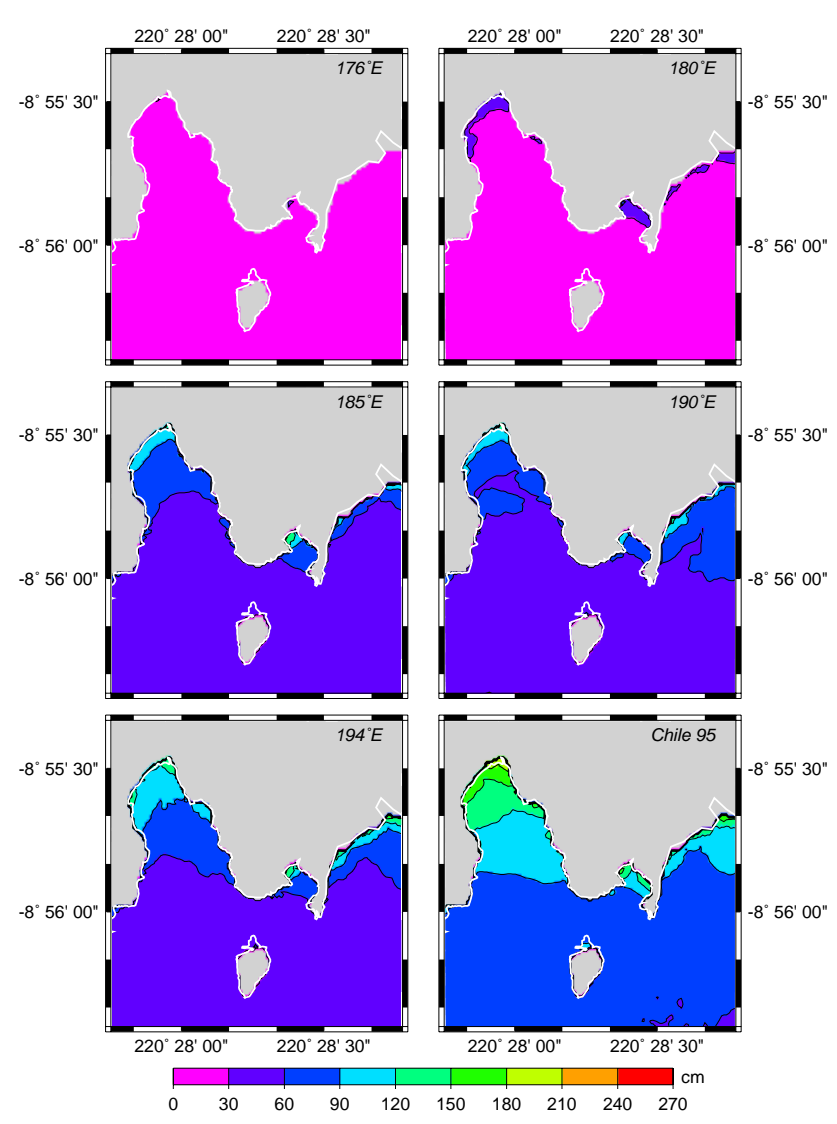

Fig. 5. Maximum water heights computed for the five Aleutian and the Chilean 1995 tsunamis in the Hane Bay (Ua Huka Island), with a $2 \mathrm{~h}$ tsunami propagation time within the archipelago. The white line is the initial shoreline.

Table 2. Parameters of the epicenters used for tsunami simulations in the Tonga trench, with the shifted Chilean 1995 source, and a fault geometry, as explained in Table 1 . For the $25^{\circ} \mathrm{S}$ epicenter, two additional strike angles $\left(160^{\circ}\right.$ and $\left.200^{\circ}\right)$ have already been tested

\begin{tabular}{cccccc}
\hline Latitude & $16^{\circ} \mathrm{S}$ & $18.5^{\circ} \mathrm{S}$ & $21^{\circ} \mathrm{S}$ & $23^{\circ} \mathrm{S}$ & $25^{\circ} \mathrm{S}$ \\
Longitude & $187.8^{\circ} \mathrm{E}$ & $187.4^{\circ} \mathrm{E}$ & $186.5^{\circ} \mathrm{E}$ & $185.4^{\circ} \mathrm{E}$ & $184.85^{\circ} \mathrm{E}$ \\
Strike & $178^{\circ}$ & $200^{\circ}$ & $205^{\circ}$ & $210^{\circ}$ & $180^{\circ}$ \\
\hline
\end{tabular}

located seaward with respect to our chosen epicenters (Johnson and Satake, 1997), and the source mechanism was probably not as simple as ours. In addition, the magnitude was much higher (8.6) than our generic source, and all of these differences could account for the huge inundations reported in 1946 in the Marquesas.

\section{Simulation of tsunamis initiated in the Tonga trench}

Due to its proximity to French Polynesia, the Tonga subduction zone deserves a thorough investigation of potential tsunamigenic seismic sources. Several large earthquakes $M>7$ have occurred in the subduction zone historically,

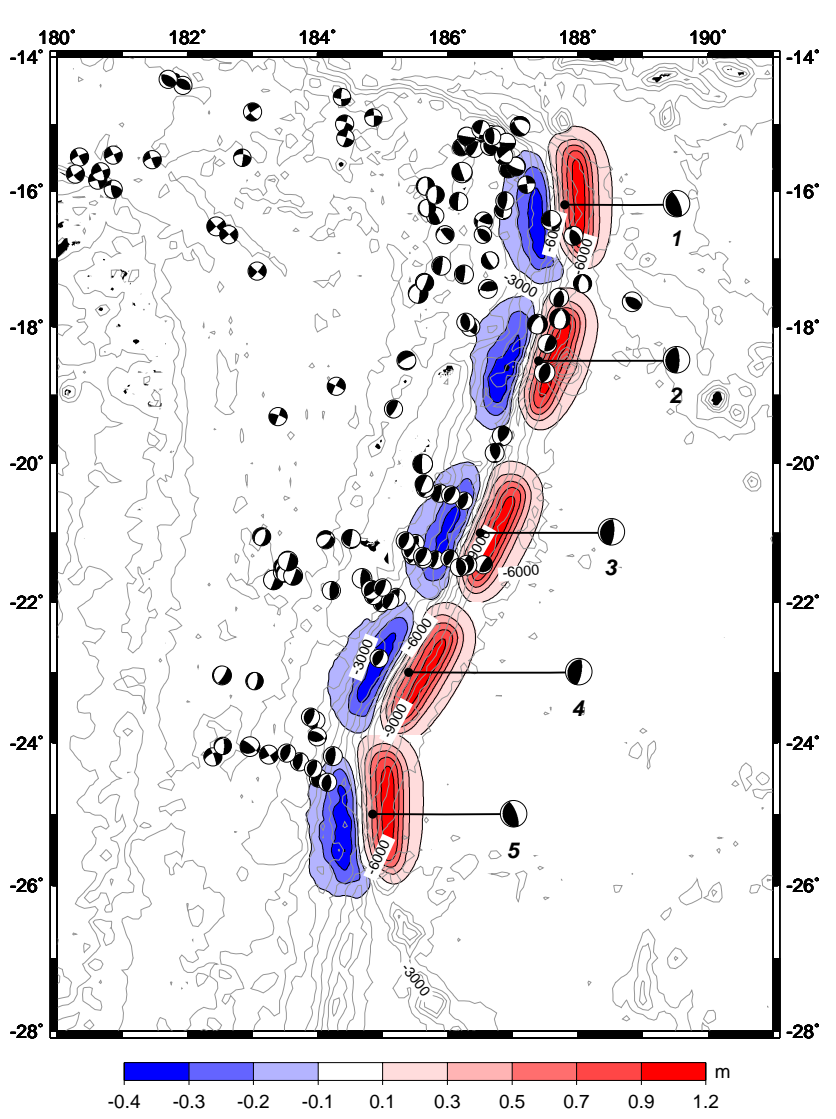

Fig. 6. Initial coseismic sea-floor deformations computed with the Okada (1985) formula for the five cases studied in the Tonga subduction zone. The five focal mechanisms are plotted with the parameters used for our computations (see Table 2). Other focal mechanisms from the Harvard CMT database display the seismicity since 1980 for $M_{w}$ magnitudes larger than 5.5. Bathymetric contours (each $1000 \mathrm{~m}$ ) are from the Smith and Sandwell (1997) data.

but large thrusting events seem relatively rare (Christensen and Lay, 1988), possibly favouring a model where interplate coupling is low (Lundgren and Okal, 1988). In addition, large tsunamis initiated in this source area have not been reported in the Marquesas archipelago. In this study, tests have been carried out for five sources located between $16^{\circ} \mathrm{S}$ and $25^{\circ} \mathrm{S}$, by letting the strike angle of the fault vary within the Tonga subduction (Table 2). Coseismic deformations computed with the Okada (1985) formula are shown in Fig. 6, with values similar to the ones in Fig. 2.

\subsection{Behaviour in the Pacific Ocean}

Figure 7 displays the maximum water heights computed in the Pacific Ocean for the five generic tsunamis generated in the Tonga region. We observe that the pattern of the maximum water heights is scattered by submarine sea-floor features, resulting in an irregular spatial extent for the tsunami energy. For instance, in each case, a band of high energy is directed to the north of the Marquesas archipelago, especially intensified for the $16^{\circ} \mathrm{S}$ source. On average, the 

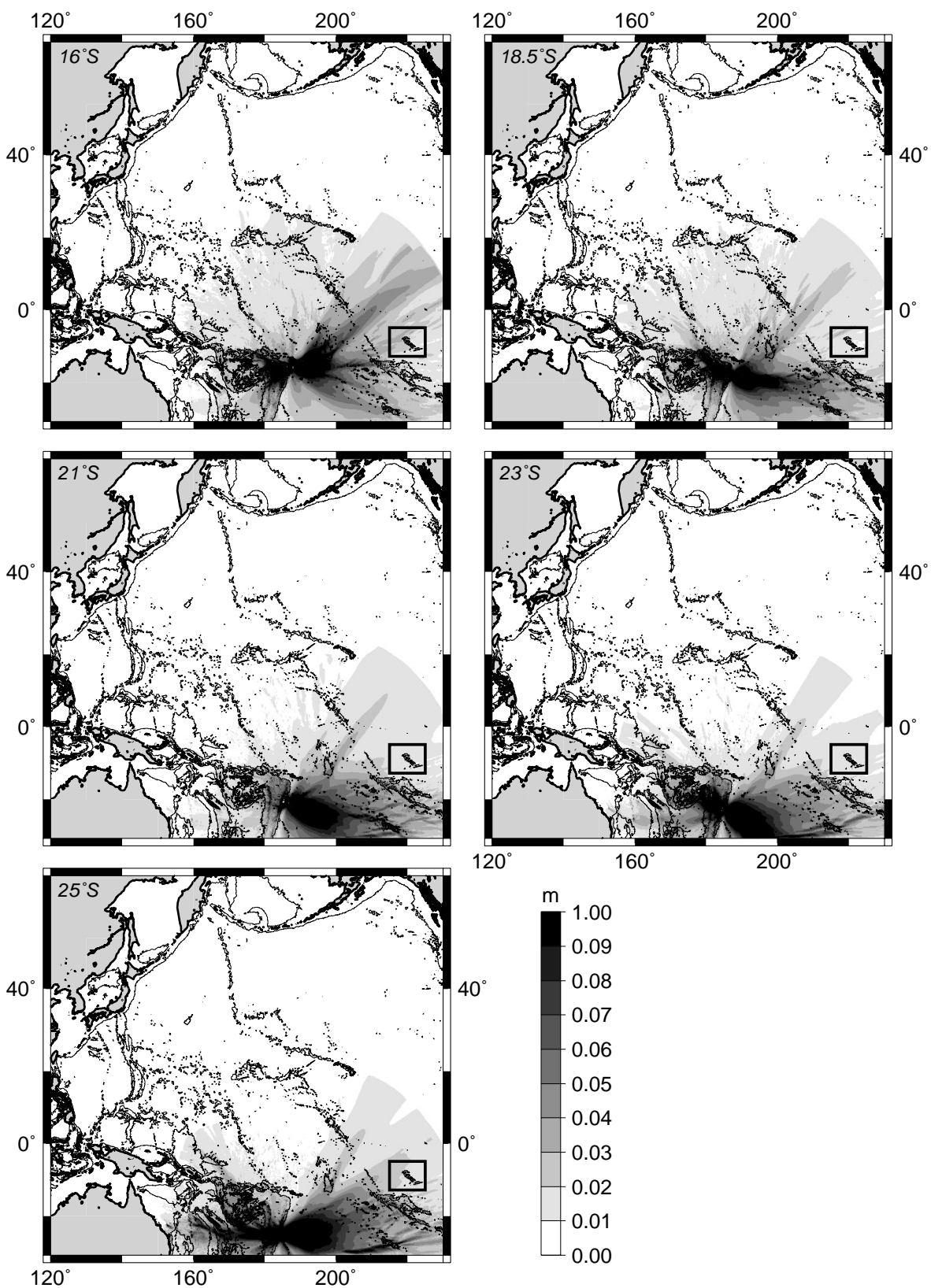

Fig. 7. Maximum water heights computed in the Pacific Ocean for the five tsunamis generated at the Tonga trench $\left(16^{\circ} \mathrm{S}, 18.5^{\circ} \mathrm{S}, 21^{\circ} \mathrm{S}, 23^{\circ} \mathrm{S}\right.$ and $25^{\circ} \mathrm{S}$ ). Average maximum water heights reaching the Marquesas archipelago range from 1 to $3 \mathrm{~cm}$.

maximum water heights reaching the Marquesas archipelago range from at least $1 \mathrm{~cm}$ to about $3 \mathrm{~cm}$, quite similar to results previously obtained for sources in the Aleutian trench. We also note that, on average, strike angles consistent with the mean trench direction and approximately perpendicular to the Marquesas archipelago are not numerous; thus, the maximum tsunami energy is rarely directed towards the archipelago.

\subsection{Behaviour in the bays}

Figure 8 shows the amplification computed in each bay for the five theoretical tsunamis characterized by the same initial seismic moment, following the method described for Fig. 4. Values obtained at gages A range from about 1.5 to $2.5 \mathrm{~cm}$, and are slightly larger than the values obtained for the Aleutian tsunamis. The $16^{\circ} \mathrm{S}$ tsunami leads to the maximum amplification for all bays, especially in the Hane and Hakahau bays. The $18.5^{\circ} \mathrm{S}, 21^{\circ} \mathrm{S}$ and $23^{\circ} \mathrm{S}$ cases display the lowest water heights for the four bays. In spite of the largest distance and the southernmost latitude, we remark that the $25^{\circ} \mathrm{S}$ case produces larger wave heights than the $19^{\circ} \mathrm{S}$ to $23^{\circ} \mathrm{S}$ cases. Indeed, in that case (see Fig. 6 and Table 2), the strike angle used is $180^{\circ} \mathrm{E}$, in agreement with the local trench direction, and this produces a maximum energy more in the direction of the Marquesas archipelago (see Fig. 7). We also note that the $16^{\circ} \mathrm{S}$ source produces higher amplifications than the Chilean 1995 event in the Hane and Hakahau bays. However, the Ua Pou and Ua Huka studied bays seem 

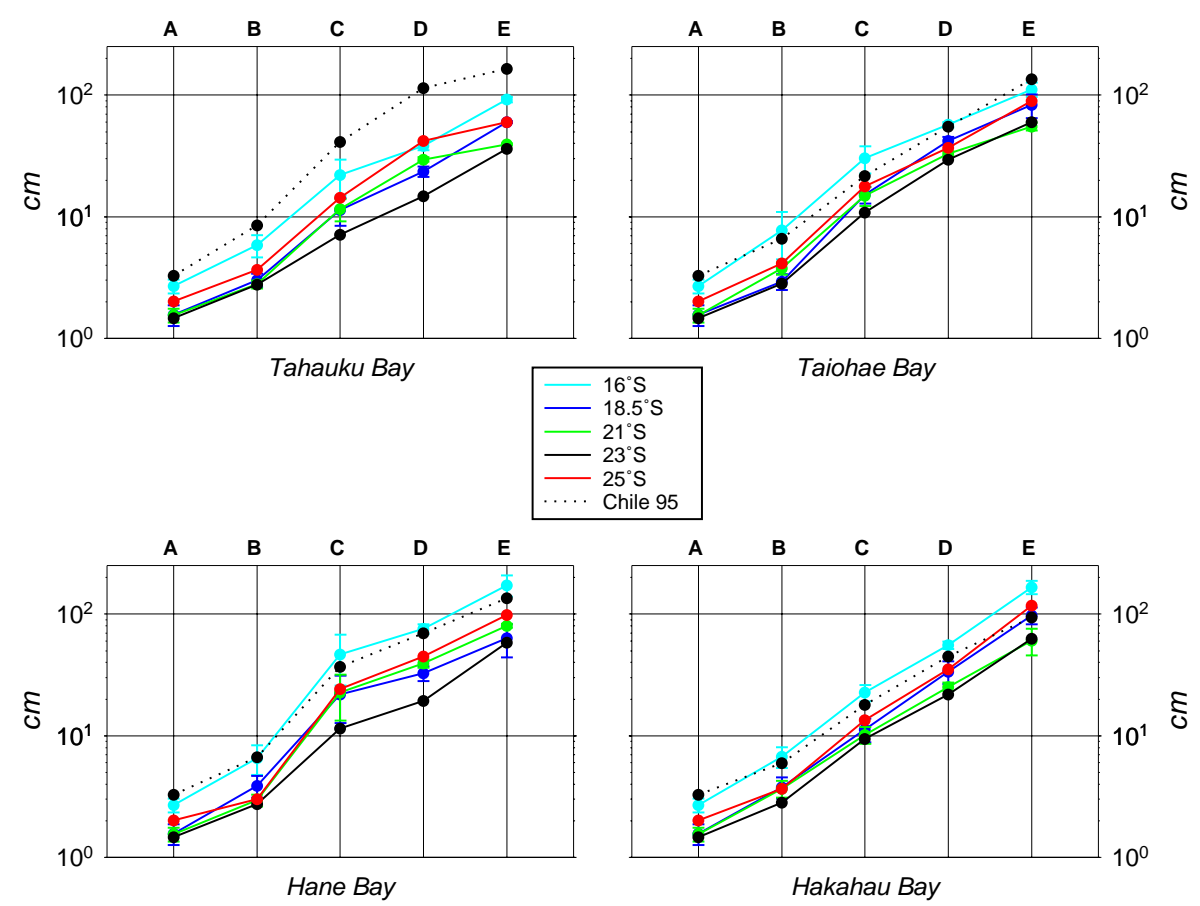

Fig. 8. Amplification functions plotted for the five simulated Tonga tsunamis, for the four studied bays (see Fig. 4 for explanation of A, B, C, D and E). Values obtained at gages A are slightly larger than values obtained at gages $\mathrm{A}$ for the Aleuina sources.

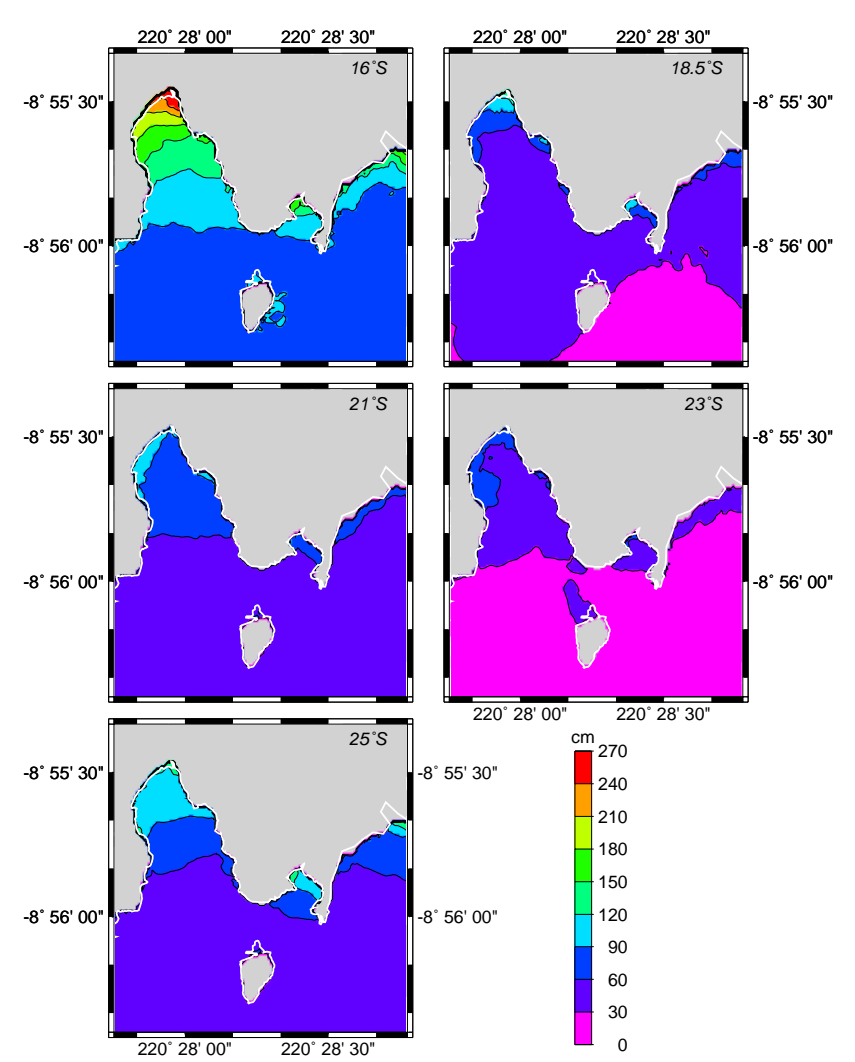

Fig. 9. Maximum water heights computed for the five Tonga tsunamis in the Hane Bay (Ua Huka Island), with a $2 \mathrm{~h}$ tsunami propagation time within the archipelago.

to be similarly protected from Tonga arrival azimuths or from a Chilean arrival azimuth (see Fig. 1). The main difference is the high energy that arrives close to the archipelago for the $16^{\circ} \mathrm{S}$ source (almost $2 \mathrm{~cm}$ at gages A), that is close to the energy of the Chilean event. The short propagation time may account for, in that case, together with a favourable azimuth, the observed important amplification.

Figure 9 displays the maximum water heights computed in the Hane Bay for the same events, $2 \mathrm{~h}$ after the arrival of the first tsunami wave in the archipelago. For the $23^{\circ} \mathrm{S}$ case the maximum water heights do not exceed $90 \mathrm{~cm}$ at the northern extremity of the bay. For the $18.5^{\circ} \mathrm{S}, 21^{\circ} \mathrm{S}$ and $25^{\circ} \mathrm{S}$ cases, the maximum water heights reach almost $120 \mathrm{~cm}$ at the northern extremity of the bay. The $16^{\circ} \mathrm{S}$ case provokes, as expected from Fig. 8, the highest computed wave heights in the bay, with about $270 \mathrm{~cm}$ near the mouth of the river, larger than the $200 \mathrm{~cm}$ obtained for the 1995 Chilean tsunami.

\subsection{Influence of the fault strike angle}

Our results show the highest amplifications either for a source located at $16^{\circ} \mathrm{S}$ in the northern Tonga trench, or for a source at $25^{\circ} \mathrm{S}$ with a $180^{\circ}$ strike angle. The key parameter controlling the final amplification seems to be the fault strike angle that defines the oceanic domain where the maximum tsunami energy will be trapped and scattered. In order to separate the effect of the strike from the effect of the location, we have finally performed several tests for the southernmost $25^{\circ} \mathrm{S}$ location, a place where the Louisville Ridge subducts and where the seismicity and active faulting pattern is rather complicated (Christensen and Lay, 1988). For this reason, the strike angle $\left(180^{\circ}\right)$ used in the first modeling may not be the value really involved in future earthquakes; thus, we used 

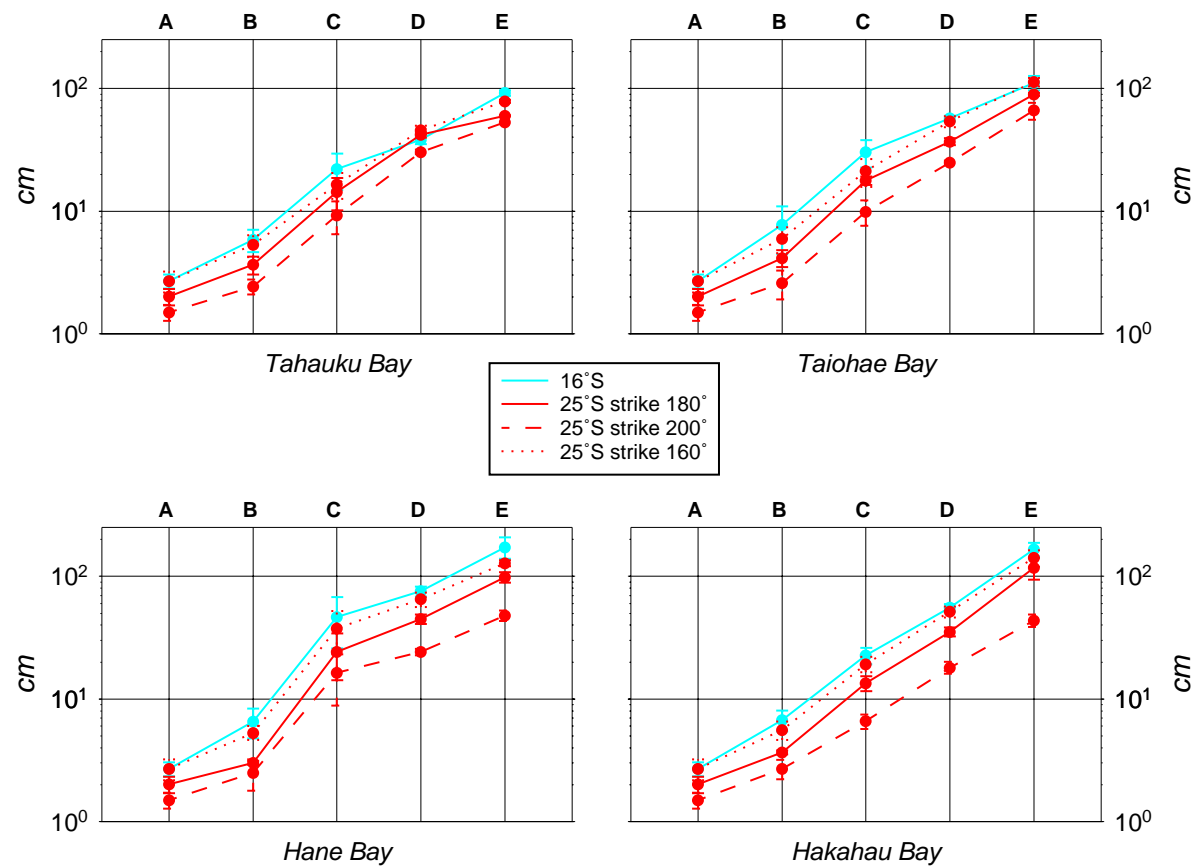

Fig. 10. Amplification functions for each studied bay, for the tests on the strike angles at the Tonga $25^{\circ} \mathrm{S}$ source. Three different strike angles $\left(160^{\circ}\right.$, $180^{\circ}$, and $200^{\circ}$ ) have been tested and are compared to the Tonga $16^{\circ} \mathrm{S}$ source (see Fig. 4 for explanation of A, B, C, $\mathrm{D}$ and $\mathrm{E})$. extreme values of $160^{\circ}$ and $200^{\circ}$ in two additional computations. Figure 10 displays the amplifications obtained in the four Marquesas bays, compared to amplifications computed for the $16^{\circ} \mathrm{S}$ source. We observe that a $160^{\circ}$ strike implies a large amplification in all bays, even close to the amplification obtained for the $16^{\circ} \mathrm{S}$ location in the Tahauka and Taiohae bays. By contrast, a $200^{\circ}$ strike produces low values at gages $\mathrm{E}(50$ to $80 \mathrm{~cm})$. This test confirms that, for a given location and source energy, the parameter controlling the final amplification is the fault strike. The strike angle is close to the mean trench azimuth, but occasionally it can take a larger set of values. Since it has already been proposed (Titov et al., 1999), we show here that, in terms of a tsunami alert following a strong earthquake, it is of primary interest to obtain as quickly as possible, not only the precise location, but also an accurate value of the involved fault strike.

\section{Conclusions}

We performed in this study several tsunami simulations in the Marquesas archipelago, based on a constant seismic moment source located in two threatening seismogenic subduction zones at the Pacific Rim: the Aleutian and Tonga trenches. The results show that the Marquesas archipelago is not immune to tsunamis generated by earthquakes located in the eastern part of the Aleutian trench and the northern part of the Tonga trench. Sea-floor features can reduce the number of potentially dangerous tsunamis. For instance, the western part of the Aleutian trench seems to be inoffensive regarding French Polynesia, due to the influence of the Hawaiian Ridge. Our simulations emphasize the major dependence of the tsunami energy arriving at the Marquesas Islands on the source location and on the arrival azimuth. More specifically, the knowledge of the fault strike is essential. This has to be kept in mind when considering the potentially tsunamigenic, very energetic earthquake which is expected to occur within the next 20 years in the emplacement of the north Chilean gap (Monge and Mendoza, 1993). Above all, the quick determination of focal mechanisms is essential to assess realtime hazards in remote areas and efforts are currently being undertaken to this end (Reymond and Okal, 2000).

Acknowledgements. This work was supported by UNESCO contract D3809. We are grateful to the technical services of French Polynesia in Tahiti for providing us with topographic data on the four studied Marquesas bays. We thank both anonymous reviewers who helped us to improve our first draft and to redefine the scope of this study. Figures were created using the Generic Mapping Tools package by Wessel and Smith (1998).

\section{References}

Barrientos, S. E. and Ward, S. N.: The 1960 Chile earthquake: inversion for slip distribution from surface deformation, Geophys. J. Int., 103, 589-598, 1990.

Christensen, D. H. and Lay, T.: Large earthquakes in the Tonga region associated with subduction of the Louisville Ridge, J. Geophys. Res., 93, 13 367-13 389, 1988.

Cifuentes, I. L. and Silver, P. G.: Low-frequency source characteristics of the great 1960 Chilean earthquake, J. Geophys. Res., 94, 643-663, 1989.

Courboulex, F., Singh, S. K., Pacheco J. F., and Ammon, C. J.: The 1995 Colima-Jalisco, Mexico, earthquake $\left(M_{w} 8.0\right)$ : A study of the rupture process, Geophys. Res. Lett., 24, 1019-1022, 1997.

Dziewonski, A. M., Ekström, G., Franzen, J. E., and Woodhouse, J. H.: Global seismicity of 1977; centroid-moment tensor solu- 
tions for 471 earthquakes, Phys. Earth Planet. Inter., 45, 11-36, 1987.

Guibourg, S., Heinrich, P., and Roche, R.: Numerical modeling of the 1995 Chilean tsunami. Impact on French Polynesia, Geophys. Res. Lett., 24, 775-778, 1997.

Hébert, H., Heinrich, P., Schindelé, F., and Piatanesi, A.: Far-field simulation of tsunami propagation in the Pacific Ocean: impact on the Marquesas Islands (French Polynesia), J. Geophys. Res., 106, C5, 9161-9177, 2001.

Hébert, H., Piatanesi, A., Heinrich, P., Schindelé, F., and Okal, E. A.: Numerical modeling of the September 13, 1999 landslide and tsunami on Fatu Hiva Island (French Polynesia), Geophys. Res. Lett., in press.

Heinrich, P., Guibourg, S., and Roche, R.: Numerical modeling of the 1960 Chilean tsunami: Impact on French Polynesia, Phys. and Chem. Earth, 21, 19-25, 1996.

Heinrich, P., Schindelé, F., Guibourg, S., and Ihmlé, P.: Modeling of the February 1996 Peruvian tsunami, Geophys. Res. Lett., 25, 2687-2690, 1998.

Ihmlé, P., Gomez, J.-M., Heinrich, P., and Guibourg, S.: The 1996 Peru tsunamigenic earthquake: broadband source process, Geophys. Res. Lett., 25, 2691-2694, 1998.

Johnson, J. M. and Satake, K.: Estimation of the seismic moment and slip distribution of the 1 April 1946, Aleutian tsunami earthquake, J. Geophys. Res., 102, 11 765-11774, 1997.

Lundgren, P. R. and Okal, E. A.: Slab decoupling in the Tonga Arc: the 22 June 1977 earthquake, J. Geophys. Res., 93, 13 355$13366,1988$.

Mendoza, C. and Hartzell, S.: Fault-slip distribution of the 1995 Colima-Jalisco, Mexico, earthquake, Bull. Seismol. Soc. Am., 89, 1339-1344, 1999.

Mofjeld, H. O., Titov, V. V., Gonzalez, F. I., and Newman, C. J.:
Analytic theory of tsunami wave scattering in the open ocean with application to the North Pacific, NOAA Tech. Memo., ERL PMEL-116, 38, Pac. Mar. Environ. Lab., Seattle, Wash., 2000.

Monge, J. and Mendoza, J.: Study of the effects of tsunami on the coastal cities of the region of Tarapacà, north Chile, Tectonophysics, 218, 237-246, 1993.

Okada, Y.: Surface deformation due to shear and tensile faults in a half-space, Bull. Seismol. Soc. Am., 75, 1135-1154, 1985.

Ozawa, S.: Geodetic inversion for the fault model of the 1994 Shikotan earthquake, Geophys. Res. Lett., 23, 2009-2012, 1996.

Piatanesi, A., Heinrich, P., and Tinti, S.: The 4 October 1994 Shikotan (Kurile Islands) tsunamigenic earthquake: An open problem on the source mechanism, Pure Appl. Geophys., 154, 555-574, 1999.

Reymond, D. and Okal, E. A.: Preliminary determination of focal mechanisms from the inversion of spectral amplitudes of mantle waves, Physics Earth Planet. Inter., 121, 249-271, 2000.

Ruegg, J. C., et al.: The $M_{w}=8.1$ Antofagasta (north Chile) earthquake of 30 July 1995: First results from teleseismic and geodetic data, Geophys. Res. Lett., 23, 917-920, 1996.

Smith, W. H. F. and Sandwell, D. T.: Global seafloor topography from satellite altimetry and ship depth soundings, Science, 277, 1956-1962, 1997.

Tanioka, Y., Ruff, L., and Satake, K.: The great Kurile earthquake of 4 October 1994 tore the slab, Geophys. Res. Lett., 22, 1661$1664,1995$.

Titov, V. V, Mofjeld, H. O., Gonzalez, F. I., and Newman, J. C.: Offshore forecasting of Alaska-Aleutian subduction zone tsunamis in Hawaii, NOAA Tech. Memorandum, ERL PMEL-114, PMEL, Seattle, WA, 22, 1999.

Wessel, P. and Smith, W. H. F.: New, improved version of Generic Mapping Tools released, Eos Trans. AGU, 79, 47, 579, 1998. 